\title{
Phytochemical Screening and in Vitro Ovicidal, Larvacidal, and Nematicidal Effects of Murraya paniculata (L.) Jack Extract on Gastrointestinal Parasites of Goats
}

\author{
G. E. Tresia ${ }^{a}$, D. Evvyernie ${ }^{b *}, \&$ R. Tiuria ${ }^{c}$ \\ a Study Program of Nutrition and Feed Science, Faculty of Animal Science, Postgraduate School, \\ Bogor Agricultural University \\ ${ }^{b}$ Department of Nutrition and Feed Science, Faculty of Animal Science, Bogor Agricultural University \\ ${ }^{c}$ Department of Parasitology and Helminthology, Faculty of Veterinary, Bogor Agricultural University \\ Jalan Agatis, Kampus IPB Darmaga Bogor 16680, Indonesia \\ (Received 10-06-2016; Reviewed 01-08-2016; Accepted 23-11-2016)
}

\begin{abstract}
In our previous research, kemuning leaves (Murraya paniculata L. Jack) was shown to have the capability as an anthelmintic candidate for PE (Ettawa crossbred) lactating dairy goats by reducing $43.67 \%$ of the egg per gram (EPG) of Strongylida compared to $0.0005 \%$ in orally treated with Oxfendazole as a control. To confirm it, the aim of this in vitro study was to determine the effective dosage of kemuning leaves from two extraction methods (infuse and maceration) to reduce the Trichostrongylidae and to evaluate the bioactive compounds of the leaves. The research was conducted using a randomized complete design with 11 treatments and 5 replications. The treatments consisted of control $(0.0005 \%$ and $0.005 \%$ Oxfendazole), kemuning leaves infuse extract (KIE) and maceration extract (KME) each with level of $1 \%, 3 \%, 5 \%$, and $7 \%(w / v)$. The results showed that the $\mathrm{LT}_{50}$ gradually decreased (shortening the lethal time) and the mortality of Trichostrongylidae gradually increased associated with the increased concentration of treatment $(P<0.01)$. The infusion of $7 \%$ kemuning extract demonstrated the highest efficiency in reducing the larval development, infective larvae, and the adult Trichostrongylidae by $93.16 \%, 94.39 \%$, and $90 \%$, respectively. This treatment could be developed as the most prospective herbal anthelmintic drug in controlling the infection by Trichostrongylidae.
\end{abstract}

Key words: infusion, kemuning (Murraya paniculata L. Jack), maceration, Trichostrongylidae

\section{ABSTRAK}

Penelitian kami sebelumnya menunjukkan bahwa herbal daun kemuning (Murraya paniculata L. Jack) memiliki kemampuan sebagai kandidat obat cacing pada ternak kambing PE (Peranakan Ettawa) laktasi yang dapat mengurangi telur tiap gram tinja (TTGT) dari Strongylida sebesar $43,67 \%$ dibandingkan dengan pemberian oxfendazole $0,0005 \%$ secara oral sebagai kontrol. Untuk mengkonfirmasi hasil tersebut, penelitian secara in vitro ini bertujuan untuk menentukan dosis efektif daun kemuning dengan dua metode ekstraksi (infusa dan maserasi) dalam mereduksi Trichostrongylidae dan mengidentifikasi senyawa bioaktif yang terkandung dalam daun kemuning. Penelitian ini menggunakan rancangan acak lengkap (RAL) dengan 11 perlakuan dan 5 ulangan. Perlakuan terdiri atas kontrol $(0,0005 \%$ dan $0,005 \%$ Oxfendazole), ekstrak infusa daun kemuning (KIE) dan ekstrak maserasi (KME) dengan tingkatan 1\%, 3\%, 5\%, dan 7\% (b/v). Hasil penelitian menunjukkan bahwa $\mathbf{L T}_{50}$ secara bertahap menurun (mempersingkat) dan kematian Trichostrongylidae secara bertahap meningkat seiring meningkatnya konsentrasi perlakuan $(\mathrm{P}<0,01)$. Ekstrak infusa (KIE) $7 \%$ memiliki efektivitas paling tinggi dalam menurunkan perkembangan larva, larva infektif, dan cacing dewasa Trichostrongylidae (masing-masing 93,14\%; 94,39\%; dan 90\%). Dapat disimpulkan bahwa secara in vitro $7 \%$ ekstrak infusa daun kemuning (KIE) dapat dikembangkan sebagai kandidat terbaik herbal obat cacing dalam mengendalikan infeksi Trichostrongylidae.

Kata kunci: infusa, kemuning (Murraya paniculata L. Jack), maserasi, Trichostrongylidae

*Corresponding author:

E-mail: erniedea8492@gmail.com 


\section{INTRODUCTION}

Nematodes are often found in the gastrointestinal tract of goats and mostly from Ordo Strongylida, Family Trichostrongylidae which produce strongylid-type eggs. A parasitic infection caused by the gastrointestinal nematodes is one of the common diseases in goats. This infection accounts for significant economic loss due to weight loss, delayed growth, and reduced milk production by $6.25 \%-21.5 \%$ (Alberti et al. 2009). The parasites are controlled with anthelmintic drugs. Repeated administration of the anthelmintic, especially the synthetic ones, is a common method (Molento et al., 2011). This method, however, has some adverse effects, such as the development of drug-resistant strains of worms and the presence of drug residues in the derived products (Kinsella et al., 2009). This condition encourages the search for new active compounds which are safer and more efficient. Medicinal plants could be an alternative for the problem.

As a tropical country, Indonesia has high biodiversity, including the medicinal/herbal plants. The efficacy of herbs is determined from the absence of clinical symptoms and improvement of performance of the patients. The knowledge on this recovery process is usually obtained from experience, being passed down through generations but this emphirical efficacy needs scientifical and pharmacological testing. Plants offer advantages over synthetic drugs for being more vastly available, environmentally friendly, and more effective to control parasitic worms.

Kemuning belongs to Class Magnoliopside, Ordo Geraniales, Family Rutaceae, Genus Murraya, and Species Murraya paniculata. The bioactive compounds in its leaves vary according to the solvent used during extraction and the growing media (Gautam et al., 2012; Vaghasiya et al., 2012; Syahadat \& Aziz, 2012). Generally, they include flavonoids, saponins, and tannins, posing a high potential for antioxidant, anticancer, antimicrobial, and antidiabetic agent ( $\mathrm{Ng}$ et al., 2012).

Our previous study showed that the administration of $0.7 \%$ kemuning leave meal (KLM) into the feed reduced the egg number per gram feces (EPG) by $21.28 \%$ at the fourth week in lactating Ettawa crossbred goats (average milk production $940 \mathrm{~mL} / \mathrm{head} / \mathrm{d}$ ) which were infected by natural parasite of Ordo Strongylida. The EPG reduction increased to $43.6 \%$ at the fifth week when then the concentration of KLM being increased to $1 \%$. Lactating Ettawa crossbred goats (average milk production of $861 \mathrm{~mL} / \mathrm{head} / \mathrm{d}$ ) which have a similar infection and were treated with Oxfendazole, were used as a control. The same positive effects were observed with both treatments, including a detected improvement on blood profiles (close to normal) and a reduction of somatic cell count in the milk. This condition implied that although the administration of KLM could not increase the milk production, it did improve the health status of the lactating Ettawa grade goats. Apparently, the right dose to significantly reduce the effect of parasitic infection was yet to be searched. This study tested the in vitro effective dose of kemuning leave extract as anthelmintic agents that can both inhibit the larval development and reduce the number of the adults.

\section{MATERIALS AND METHODS}

\section{Research Design}

Control, kemuning infuse extract (KIE), kemuning maceration extract (KME), and Oxfendazole (OXF) were compared in this research. The experiment consisted 11 treatments $(\mathrm{P} 0=$ Control; $\mathrm{P} 1=\mathrm{KIE} 1 \%$; $\mathrm{P} 2=\mathrm{KIE} \mathrm{3 \%}$; $\mathrm{P}=$ KIE 5\%; P4= KIE 7\%; P5= KME 1\%; P6= KME 3\%; P7= $\mathrm{KME} \mathrm{5 \%}$; P8= KME 7\%; P9= OXF 0.0005\%; dan P10= OXF $0.005 \%$ ) with 5 replications.

\section{Extraction Procedure (Depkes, 2000)}

Infuse method. Kemuning leaves meal (KLM) was diluted with distilled water $(1: 10 \mathrm{w} / \mathrm{v})$, and the solution was placed into an infused pan, stirred, heated for 15 min at $90^{\circ} \mathrm{C}$, and filtered with filter cloth. The process was repeated several times for the same KLM. The filtrate was concentrated by spray drying (mini spray dry Buchi 190). This extract was used in in vitro test.

Maceration method. KLM was diluted in 96\% ethanol $(1: 10 \mathrm{w} / \mathrm{v})$, left for $24 \mathrm{~h}$, and filtered. The process was repeated several times for the same KLM. The solvent was removed with vacuum rotary evaporator (Buchi Rotavapor R-205) at $55^{\circ} \mathrm{C}$. This extract was used in in vitro test. The yield of the extract was calculated as: Yield $(\%)=[$ Extract mass $(\mathrm{g}) /$ KLM mass $(\mathrm{g})] \times 100 \%$

\section{Phytochemical Analysis (Harbone, 1987)}

Alkaloid test. KLM sample (1-2 g) was mixed with chloroform-ammonia solution $(10 \mathrm{~mL})$ and filtered. Some drops of $\mathrm{H}_{2} \mathrm{SO}_{42} \mathrm{~N}$ were added to the filtrate and the solution was shaken until 2 distinct layers were formed. The acid layer (no color) was pipetted into another reaction tube and divided into 3. Some drops of Dragendrorf, Mayer, and Wagner reagents were added into each of them. Positive result is indicated by the formation of orange, white-yellowish, and brown precipitation following the addition of Dragendrorf, Mayer, and Wagner reagent, respectively.

Flavonoid test. The sample was added with few $\mathrm{mL}$ of ethanol or distilled water until completely soaked, followed by boiling and filtration. Few drops of $10 \%$ $\mathrm{NaOH}$ were added which would result in the formation of yellow color. This color should fade out when being added with concentrated $\mathrm{H}_{2} \mathrm{SO}_{4}$, indicating the presence of flavonoid.

Saponin and tannin test. The sample was diluted with hot distilled water, boiled, and filtered. The filtrate was divided into 2 reaction tubes, each for saponin and tannin test. The one for saponin test was cooled down and shaken manually. A positive result would be indicated by the formation of stable foam layer (lasts for $10 \mathrm{~min}$ ) $>1 \mathrm{~cm}$ in height. For tannin test, $1 \% \mathrm{FeCl}_{3}$ was added 
into the filtrate. A positive result would be indicated by the formation of green, blue, and black colors.

Triterpenoid and steroid test. Sample was diluted with $25 \mathrm{~mL}$ of ethanol $\left(50^{\circ} \mathrm{C}\right)$, filtered into a porcelain dish, and let to evaporate. Ether was added to the residue. The ether extract was transferred to drop plate and was added with 3 drops of $\left(\mathrm{CH}_{3} \mathrm{CO}\right)_{2} \mathrm{O}$ and one drop of concentrated $\mathrm{H}_{2} \mathrm{SO}_{4}$ (Lieberman-Burchard test). Formation of red-violet and green color would indicate the presence of triterpenoid and steroid, respectively.

\section{Quantitative Phytochemical Analysis (Depkes, 2009)}

The color intensity from the positive qualitative tests was quantitatively assessed. The analyses were as follow:

Analysis of flavonoids (as quercetin). Sample (1 g) was added distilled water and refluxed for $3 \mathrm{~h}$. The volume was then adjusted to $500 \mathrm{~mL}$ with distilled water. After filtration, $1 \mathrm{~mL}$ of the filtrate was added $2 \mathrm{~mL}$ of FolinDenis and $5 \mathrm{~mL}$ of $\mathrm{Na}_{2} \mathrm{CO}_{3}$ Denis anhydrous and adjusted to $500 \mathrm{~mL}$ volume with $100 \mathrm{~mL}$ distilled water. From tannic acid solution (100 ppm), the standard was made with concentrations of 0 ppm, 1 ppm, 2 ppm, 3 ppm, 4 ppm, 5 ppm. Samples and standards were measured for their absorbance with a spectrophotometer at $725 \mathrm{~nm}$ (Hitachi U-2000 250 V).

Analysis of saponins. Sample ( $\pm 1 \mathrm{~g})$ in $25 \mathrm{~mL}$ volumetric flasks was added with distilled water up to a quarter of the flask's volume and was refluxed for $2 \mathrm{~h}$. The volume was then adjusted to $25 \mathrm{~mL}$ with distilled water followed by $24 \mathrm{~h}$ storage. After filtration, some filtrate $(\mu \mathrm{L})$ was applied on aluminum plate silica gel 60 GF 254 with $5 \mu \mathrm{L}$ of water-diluted saponin (190 ppm) as a comparison. The plate was eluted in $\mathrm{CHCl}_{3}$ :ethanol $(49: 1)$ added with some drops of ethyl acetate until it reached the limit of the eluent $( \pm 15 \mathrm{~cm})$. The plate was let to dry and detected with Thin Layer Chromatography (TLC) scanner Camag 3 at $292 \mathrm{~nm}$.

Analysis of tannins. From tannic acid solution $(0.1 \mathrm{mg} /$ $\mathrm{mL}$ ) as the standard, $0.02 \mathrm{~mL}, 0.04 \mathrm{~mL}, 0.06 \mathrm{~mL}, 0.08$ $\mathrm{mL}$, and $0.10 \mathrm{~mL}$ were taken and added with $0.5 \mathrm{~mL}$ distilled water, $0.25 \mathrm{~mL}$ Folin-Ciocalteu reagent, and $1.25 \mathrm{~mL} \mathrm{NaCO}$ solution. The solution was vortexed and measured for their absorbance with a spectrophotometer at $725 \mathrm{~nm}$. The sample solution was diluted $6 \mathrm{x}$ with distilled water. Then, $0.05 \mathrm{~mL}$ of it was taken, diluted 10x with distilled water, and treated similarly to standard solution. The tannin/saponin concentration was determined as:

[(Absorbance of sample / Absorbance of standard) $x$ tannin or saponin concentration $\left(\mathrm{g} \times 10^{-2} \mathrm{~g}\right) \times$ dilution factor]

\section{Larval Development Assay (Nery et al., 2010)}

Infective larvae were developed from the eggs collected from the feces of naturally infected goats. Feces
(4 g) were ground, mixed with vermiculite with ratio of $1: 3(\mathrm{v} / \mathrm{v})$, and added with treatments. The mixtures were placed in a petri dish (diameter $=7 \mathrm{~cm}$ ) lined with Whatman paper. The surface was leveled, covered, and stored for $7 \mathrm{~d}$ at $25-29{ }^{\circ} \mathrm{C}$. As much as $20 \mathrm{~mL}$ of the larvae-containing liquid was collected. The solution was applied to 10 objective glasses ( $0.01 \mathrm{~mL}$ each) and observed under a microscope (Nikon YS 100) with $10 \mathrm{x}$ 10 magnification. The number of infective larvae in 20 $\mathrm{mL}$ was calculated as follow:

$$
\mathrm{N} 1=[\mathrm{V} 1 \times \mathrm{N} 2] / \mathrm{V} 2
$$

with $\mathrm{N} 1=$ the number of infective larvae in $20 \mathrm{~mL}, \mathrm{~N} 2=$ number of infective larvae in $0.1 \mathrm{~mL}, \mathrm{~V} 1=$ volume of solution $20 \mathrm{~mL}, \mathrm{~V} 2=$ volume of solution $0.1 \mathrm{~mL}$.

\section{Larvicidal Assay (Akhter et al., 2015)}

Feces (300 g) were fertilized according to Akhter et al. (2015) and the larvae were harvested following modified Baermann larval collection technique (1917). The larvae-containing liquid $(0.01 \mathrm{~mL})$ was transferred into counting plate (diameter $=2 \mathrm{~cm}$ ) and added with treatments. Every hour for $4 \mathrm{~h}$, the number of larvae was observed under a microscope at $4 \times 10$ magnification within a range of 60-130 infective larvae.

\section{Identification of Infective Larvae of Trichostrongylidae (van Wyk \& Mayhew, 2013)}

Larvae-containing liquid (0.01 mL) was pipetted into the objective glass, added with lugol solution, and observed under microscope (Nikon Eclipse E600) at $10 \times 10$ magnification and with a total of 100 larvae being observed. The larvae were distinguished based on the presence of sheath, head shape, the presence of refractile, and the size of tail sheath. For every type of larvae, three larvae were measured for their length and diameter with microscope connected to a visual scaler (SVS 3000) and monitor.

\section{Nematicidal Assay (Akhter et al., 2015)}

The adult worms obtained from necropsied goats' abomasum were put in petri dish (diameter $=9 \mathrm{~cm}$ ) containing $10 \mathrm{~mL}$ of the treatment solution. The mortality, indicated by no response upon touching, was observed every $30 \mathrm{~min}$ for $6 \mathrm{~h}$.

\section{Data Analysis}

The experimental design used was completely randomized design (CRD) with 11 treatments and 5 replications. The data were analyzed with ANOVA and compared with Duncan Test in SPSS 16.0. The lethal concentration was analyzed using probit Minitab 14.0.

\section{RESULTS}

Table 1 showed that the bioactive compounds in KIE were more diverse than in KLM and KME. Flavonoids, saponin, and tannins were positively 
identified in the three of them. KIE was $2.73 \%$ lower in flavonoids as quercetin, $0.08 \%$ lower in saponins, and $0.7 \%$ higher in tannins compared to KME. The values indicated a high level of flavonoids other than quercetin in KIE.

Larvae of Trichostrongylus sp., Haemonchus sp., and Cooperia sp. which belong to the family of Trichostrongylidae were identified in coprocultures control (P0) (Table 2). The success rate of the larval development in the control group was $40 \%$. The average lethal time and percentage of mortality during larval development phase, infective larvae, and the adults of Trichostrongylidae were presented in Table 3. The analysis of variance (ANOVA) showed a gradual decrease in $\mathrm{LT}_{50}$ (shortening the lethal time) and an increase in mortality of Trichostrongylidae with increasing concentration of treatment $(\mathrm{P}<0.01)$. The $7 \%$ KIE $(\mathrm{P} 4)$ which had higher concentration of tannins, was more effective than KME (P8) and Oxfendazole (P10) in inhibiting larval development, infective larvae (L3), and adult Trichostrongylidae (by 93.14\%, 94.39\%, and 90\% respectively). It was expected that this concentration of KIE contained $0.04 \%$ quercetin, $0.09 \%$ tannins, and $0.17 \%$ saponins. Compared to the $7 \% \mathrm{KIE}$, the 5\% KIE showed the same inhibition effect toward larval development but different effect toward infective larvae (L3) and the adults. This ovicidal effect was also comparable with 7\% KME (P8) and Oxfendazole (P9 and P10). Infusion method was more effective than the maceration as a potential ovicidal, larvicidal, and nematicidal agent as the former took lower concentration than the latter to generate the same efficacy.

Figure 1 showed that higher concentration was needed to kill the adult helmints, followed by that for

Table 1. Bioactive compounds and yield of kemuning leave extract

\begin{tabular}{|c|c|c|c|c|c|c|}
\hline \multirow{2}{*}{\multicolumn{2}{|c|}{ Variables }} & $\left.\mathrm{KLM}^{*}\right)$ & \multicolumn{2}{|c|}{ Kemuning infusion extract (KIE) } & \multicolumn{2}{|c|}{ Kemuning maceration extract (KME) } \\
\hline & & Qualitative $^{1)}$ & Qualitative $^{1)}$ & Quantitative (\%) & Qualitative $^{1)}$ & Quantitative (\%) \\
\hline Yield (\%) & & - & \multicolumn{2}{|c|}{6.48} & \multicolumn{2}{|c|}{2.87} \\
\hline \multicolumn{7}{|c|}{ Bioactive coumpounds } \\
\hline \multicolumn{2}{|c|}{ Flavonoids } & +++ & +++ & $0.53^{2)}$ & +++ & $3.39^{2)}$ \\
\hline \multicolumn{2}{|l|}{ Tannins } & +++ & ++ & $1.35^{2)}$ & - & $0.65^{2)}$ \\
\hline \multicolumn{2}{|l|}{ Saponins } & ++ & ++ & $2.38^{3)}$ & ++ & $2.46^{3)}$ \\
\hline \multicolumn{2}{|l|}{ Steroids } & - & + & & +++ & \\
\hline \multicolumn{2}{|c|}{ Triterpenoidss } & - & - & & - & \\
\hline \multirow[t]{3}{*}{ Alkaloids } & Mayer & - & + & & - & \\
\hline & Wagner & - & + & & - & \\
\hline & Dragendorf & - & +++ & & - & \\
\hline Quinos & & - & - & & - & \\
\hline
\end{tabular}

Note: ${ }^{*}$ Kemuning Leave Meal; ${ }^{1)}$ Analysis in Biofarmaka Laboratory (2016); ${ }^{2)}$ Analysis in Balittro (2016); ${ }^{3)}$ Analysis in Balitnak (2016). (-) Negative, (+) Positive weak, (++) Positive, (+++) Strong positive, (++++) Very strong positive.

Table 2. Identification of infective larvae (L3) of Trichostrongylidae before treatments

\begin{tabular}{lccc}
\hline \multirow{2}{*}{ Variables } & & Genus infective larvae & \\
\cline { 2 - 4 } & Trichostrongylus sp. & Haemonchus sp. & Cooperia sp. \\
\hline Total $(\%)$ & 83.10 & 8.92 & 7.98 \\
Classification factor & & & Present \\
$\quad$ Sheat & Present & Present & Square \\
Head shape & Square & Round & Present \\
$\quad$ Refractile bodies & Absent & Absent & $33.84 \pm 3.55$ \\
Diameter $(\mu \mathrm{m})$ & $18.87 \pm 0.21$ & $22.49 \pm 1.36$ & $919.07 \pm 5.37$ \\
Lenght $(\mu \mathrm{m})$ & $653.40 \pm 39.74$ & $803.30 \pm 30.63$ & $1005 \pm 123$ \\
Literature* $(\mu \mathrm{m})$ & $730 \pm 50$ & $882.13 \pm 102.63$ & \\
Figure & & & \\
& & & \\
\end{tabular}

Note: *)Lenght of larva infective based on Van Wyk \& Mayhew (2013). 
Table 3. The average lethal time and percentage of mortality of Trichostrongylidae

\begin{tabular}{|c|c|c|c|c|c|}
\hline \multirow{2}{*}{ Treatments } & \multicolumn{3}{|c|}{ Mortality (\%) } & \multicolumn{2}{|c|}{ Lethal time 50\% (h) } \\
\hline & Adult worms & Infective larvae & Larval development & Adult worms & Infective larvae \\
\hline P0 & $4.0 \pm 5.48 \mathrm{~g}$ & $8.50 \pm 2.09^{f}$ & $0.00 \pm 0.00^{\mathrm{e}}$ & * & ** \\
\hline P1 & $16.0 \pm 5.48^{\mathrm{f}}$ & $75.39 \pm 6.46^{c}$ & $33.14 \pm 6.11^{\mathrm{d}}$ & * & $2.05 \pm 0.08^{\mathrm{cd}}$ \\
\hline P2 & $40.0 \pm 7.07^{\mathrm{d}}$ & $87.16 \pm 4.45^{\mathrm{ab}}$ & $36.48 \pm 5.78^{\mathrm{cd}}$ & * & $1.72 \pm 0.20^{\mathrm{e}}$ \\
\hline P3 & $70.0 \pm 7.07^{b}$ & $91.85 \pm 4.64^{\mathrm{ab}}$ & $88.23 \pm 3.49^{a}$ & $5.34 \pm 0.35^{\mathrm{a}}$ & $1.09 \pm 0.47^{\mathrm{f}}$ \\
\hline $\mathrm{P} 4$ & $90.0 \pm 7.07^{a}$ & $94.39 \pm 3.78^{a}$ & $93.16 \pm 5.93^{a}$ & $4.00 \pm 0.39^{b}$ & $1.09 \pm 0.45^{\mathrm{f}}$ \\
\hline P5 & $28.0 \pm 8.37 \mathrm{e}$ & $42.06 \pm 4.62^{\mathrm{e}}$ & $54.92 \pm 2.26^{\mathrm{b}}$ & * & $3.38 \pm 0.11^{\mathrm{a}}$ \\
\hline P6 & $42.0 \pm 10.95^{\mathrm{d}}$ & $61.75 \pm 6.11^{\mathrm{d}}$ & $44.91 \pm 2.76^{c}$ & * & $2.39 \pm 0.13^{b}$ \\
\hline P7 & $48.0 \pm 13.04^{\mathrm{cd}}$ & $75.58 \pm 15.56^{c}$ & $40.15 \pm 6.44^{\mathrm{cd}}$ & * & $1.83 \pm 0.36^{\mathrm{de}}$ \\
\hline P8 & $72.0 \pm 13.04^{\mathrm{b}}$ & $84.34 \pm 7.53^{b}$ & $86.64 \pm 6.44^{\mathrm{a}}$ & $4.09 \pm 1.02^{\mathrm{b}}$ & $1.72 \pm 0.22^{\mathrm{e}}$ \\
\hline P9 & $28.0 \pm 4.47^{\mathrm{d}}$ & $63.07 \pm 2.11^{\mathrm{d}}$ & $90.24 \pm 8.46^{\mathrm{a}}$ & * & $2.24 \pm 0.05^{\mathrm{bc}}$ \\
\hline P10 & $54.0 \pm 5.48^{c}$ & $73.49 \pm 2.55^{c}$ & $93.32 \pm 2.89^{\mathrm{a}}$ & $5.12 \pm 0.50^{\mathrm{a}}$ & $2.04 \pm 0.23^{\mathrm{cd}}$ \\
\hline
\end{tabular}

Note: Means in the same column with different superscript differ significantly(P<0.01). ${ }^{*}=$ percentage of mortality was less than $50 \%$; ${ }^{*}$ the time of death was more than 4 h. P0= Control; P1= KIE 1\%; P2= KIE 3\%; P3=KIE 5\%; P4=KIE 7\%; P5= KME 1\%; P6= KME 3\%; P7= KME 5\%; P8= KME 7\%; $\mathrm{P} 9=\mathrm{OXF} 0.0005 \%$; and $\mathrm{P} 10=\mathrm{OXF} 0.005 \%$. KIE= kemuning infusion extract; KME= kemuning maceration extract.

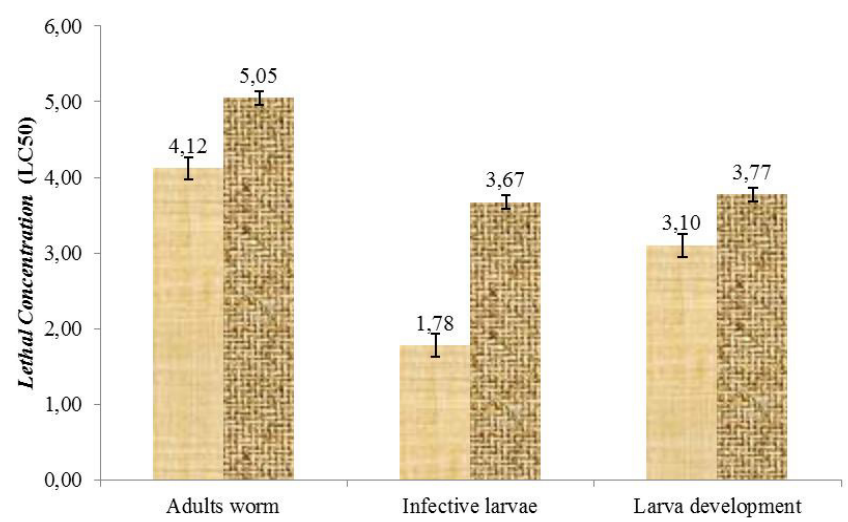

Figure 1. Lethal Concentration (LC50) of kemuning infuse extract $(\mathrm{KIE},-)$ ) and kemuning maceration extract (KME, 涟).

larval development phase and infective larvae, respectively. The concentration of KIE needed to kill the nematodes at each phase was always lower than that of KME.

\section{DISCUSSION}

\section{Bioactive Compounds and Yield of Kemuning Leave Extract}

Kemuning, especially its bioactive compounds with their various biochemical characteristics, was already known for its potential to control gastrointestinal nematodes in ruminants. To further investigate its effectiveness, two types of extracts obtained with two different solvents (ethanol and distilled water) were used. Between the two, KIE had a higher yield and bioactive compounds, especially flavonoids and tannins. This suggested that kemuning leave extract as a polar one. Possibly, the bioactive compounds were easier to be extracted in the solvent by infusion than by macera- tion, explaining the high bioactive compounds and yield in KIE. In addition to the effect of different polarities, a heating process in infusion method could increase their solubilities, although it might also reduce the tannin concentration. Khattab \& Arntfield (2009) reported that heating at $121^{\circ} \mathrm{C}$ for $20 \mathrm{~min}$ reduced tannin concentration by $1.42 \%-4.75 \%$.

The anthelmintic activity of kemuning leave extract is accounted by their high saponin and tannin content which are known as antinutrition. High consumption of tannins (4\% dry matter (DM)) and saponins (3g/day or $0.4 \% \mathrm{DM}$ ) will cause detrimental effects for ruminants, including a decrease in appetite, growth inhibition, as well as interferences in the morphology and proteolytic activity of ruminal microbes (Mao et al., 2010; Hu et al., 2006; Barman \& Rai, 2008). Based on the calculation on the usage of the concentration of the extract with total tannins or saponin level, it was estimated that $7 \% \mathrm{KIE}$ contained $0.09 \%$ and $0.17 \%$ while the same concentration of KME contained $0.04 \%$ and $0.17 \%$ of tannins and saponins respectively. It suggested that the saponins and tannins in both extracts at $7 \%$ concentration were at tolerable levels and were expected to be potential anthelmintic agents with no negative impacts on the livestock.

\section{Ovicidal, Larvicidal, and Nematicidal Activity of Kemuning Leave Extract}

In vitro test showed that the kemuning leave extracts with both infusion and maceration method were effective against Trichostrongylidae. However, KIE showed a significant anthelmintic activity against larval development, infective larvae (L3), and the adults. Similar results as in treatment P3, P4, and P8 were reported by Akhter et al. (2015) which studied the effect of infuse (10\%) and maceration (5\%) extracts of ofneem, tamak, korola flower, chatim, and sharma on infective larvae and the adults of Haemonchus contortus. However, 
different results were obtained by Nery et al. (2010) with infuse (5\%) and maceration (4\%) extract of Anarcadium humile $(5 \%)$ on larval development.

According to the classification of efficacy index by Parasitology World Association for the Advancement of Veterinary Parasitology, $>90 \%$ anthelmintic activity characterizes an effective product, $80 \%-90 \%$ for moderately effective, $60 \%-80 \%$ for less effective, and $<60 \%$ for not effective product (Nery et al., 2010). Therefore, 7\% KIE (P4) was considered effective in inhibiting larval development, infective larvae, and adult Trichostrongylidae.

The toxicity or anthelmintic activity level of a plant extract could be seen from its $\mathrm{LC}_{50}$, in which the lower the $\mathrm{LC}_{50}$, the more toxic and the higher the anthelmintic effect. It always took lower concentration for infuse extract than the maceration to generate the same mortality effect. It indicated that the former had a better anthelmintic function than the latter. Additionally, the extract concentration increased in line with the level of development phase of the nematodes. It was due to the difference in morphological development such as the difference in the structure between larval cuticle and nematodes (Page et al., 2014), metabolism, and the immune system of each phase of Trichostrongylidae.

In our previous study, the administration of KLM (equal to $1 \%$ extract) in the feed additives reduced EPG of Strongylid by $43.67 \%$ in Ettawa crossbred goats. This response was higher than the in vitro mortality level of adult worms in the current study. It suggested that the herbal mechanism of kemuning leave is more effective in inhibiting the reproduction than in causing mortality of the worms. This hypothesis was supported by Martínez-Ortíz-de-Montellano et al. (2010) who reported that the administration of tannins $(1200 \mu \mathrm{g} / \mathrm{mL})$ from tzalam reduced EPG, the fecundity (damaging the vulva), and the length of the worms.

The anthelmintic activity of kemuning leave extract is attributed to its level of flavonoids, saponins, and tannins. Saponins, tannins, and flavonoids are expected to work synergistically as anthelmintic agents. Saponins and tannins damage the cuticle of Trichostrongylidae. Saponin's main action could alter the pore shape and the cuticle permeability of the parasites while tannins could bind their cuticle protein (Kerboeuf et al., 2008; Wang et al., 2010). These mechanisms are expected to ease the diffusion of flavonoids and increase the exposure to the compounds. Tannins and flavonoids inhibit enzyme secretion (tyrosin kinase, nonspcific colinesterase, and esterase) that may cause fatal intracellular instability, such as disorganization of neuromuscular (neuron and muscle) cells and energy metabolism. These conditions would lead to impaired flexibility, paralysis, energy depletion, and eventually the death of Trichostrongylidae (Kerboeuf et al., 2008; Hoste et al., 2006). Hence, these three bioactive compounds have a potential to be alternative anthelmintic drugs. Oxfendazole or benzimidazole (BZ) derivatives have been widely used as anthelmintic drugs and are known to have a broad spectrum of actions against nematode and cestode. BZ inhibits microtubule polymerization pathway by selectively binding the $\beta$-tubulin subunit, hampering the absorption of glucose as an energy source that leads to energy depletion and death (Munguia et al., 2015).

In addition, the lethal time and mortality level of Trichostrongylidae are also affected by in vitro condition which is not $100 \%$ similar to its natural habitat (in vivo). The natural habitat of Trichostrongylidae, the goat's abomasum, produces abomasum juice containing nutrition and enzyme that support their life and $\mathrm{NaCl}$ and help in the regulation of ionic and fluidic balance.

In the previous study, kemuning leaves were used at such low amount that the reduction achieved was still $<50 \%$ even after 5 weeks of administration. The effectiveness of kemuning leaves was lower compared to Oxfendazole, in which $0.0005 \%$ of the latter (once, no replicate) could reduce EPG by $100 \%$. Additionally, it was possible that the amount of bioactive compounds being absorbed was still far from that for an optimal reduction of EPG. Hence, to confirm the potential of kemuning as an alternative to Oxfendazole, the concentration of $7 \%$ needs to escape rumen, implying that it can $90 \%$ act as anthelmintic agent. Further study was expected to modify kemuning leaves for in vivo test that allows the bioactive compounds to escape rumen and gives the same response as in this in vitro test. It is important that the administration of kemuning leaves must not negatively affect the ruminal microorganisms for they are sensitive to antinutrition.

\section{CONCLUSION}

The $7 \%$ kemuning infusion extract demonstrated the highest efficiency in reducing the larval development, infective larvae, and the adult Trichostrongylidae by $93.16 \%$, 94.39\%, and 90\%, respectively. This treatment can be developed as the most prospective herbal anthelmintic drug in controlling the infection by Trichostrongylidae.

\section{REFERENCES}

Akhter, S., A. R. Dey, S. Hossain, T. R. Dey, \& N. Begum. 2015. In vitro anthelmintic effect of some medicinal plants against Haemonchus contortus. J. Anim. Sci. Adv. 5: $1162-1170$.

Alberti, E. J., S. A. Zanzani, N. Ferrari, G. Bruni, \& M. T. Manfredi. 2012. Effects ofgastrointestinal nematodes on milk productivity in three dairy goat breeds. Small Rumin. Res. 106: 12-17. https://doi.org/10.1016/j. smallrumres.2012.04.027

Barman, K. \& S. N. Rai. 2008. In vitro nutrient digestibility, gas production and tannin metabolites of Acacia nilotica pods in goats. Asian-Australas. J. Anim. Sci. 21: 59-65. https:// doi.org/10.5713/ajas.2008.60161

Departemen Kesehatan RI. 2000. Acuan Sediaan Herbal. Direktorat Jendral POM -Depkes RI, Jakarta.

Departemen Kesehatan RI. 2009. Farmakope Herbal Indonesia. Direktorat Jendral POM -Depkes R, Jakarta.

Gautam, M. K., M. Gangwar, G. Nath, C. V. Rao, \& R. K. Goel. 2012. In-vitro antibacterial activity on human pathogens and total phenolic, flavonoid contents of Murraya paniculata Linn. Leaves. Asian. Pac. J. Trop. Biomed. 2:S1660-S1663. https://doi.org/10.1016/S2221-1691(12)60472-9

Harborne, J. B. 1987. Metode Fitokimia: Penuntun Cara Modern Menganalisa Tumbuhan. 2nd ed. Institut Teknologi Bandung, Bandung. 
Hoste, H., F. Jackson, S. Athanasiadou, S. M. Thamsborg, \& S. O. Hoskin. 2006. The effects of tannin-rich plants on parasitic nematodes in ruminants. Trends Parasitol. 22: 253-261. https://doi.org/10.1016/j.pt.2006.04.004

Hu, W. L., J. X. Liu, Y. M. Wu, Y. Q. Guo, \& J. A. Ye. 2006. Effects of tea saponins on in vitro ruminal fermentation and growth performance in growing Boer goat. Arch. Anim. Nutr. 60: 89-97. https://doi.org/10.1080/17450390500353119

Kerboeuf, D., M. Riou, \& F. Guegnard. 2008. Flavonoid and Related Compounds in Parasitic Disease Control. Mini. Rev. Med. Chem. 8: 116-128. https://doi. org/10.2174/138955708783498168

Khattab, R. Y. \& S. D. Arntfield. 2009. Nutritional quality of legume seeds as affected by some physical treatments 2 . Antinutritional factors. JFST 42:1113-1118. https://doi. org/10.1016/j.lwt.2009.02.004

Kinsella, B., S. J. Lehotay, K. Mastovska, A. R. Lightfield, A. Furey, \& M. Danaher. 2009. New method for the analysis of flukicide and other anthelmintic residues in bovine milk and liver using liquid chromatography-tandem mass spectrometry. Anal. Chim. Acta. 637: 196-207. https://doi. org/10.1016/j.aca.2008.10.072

Mao, H. L., J. K. Wang, Y. Y. Zhou, \& J. X. Liu. 2010. Effects of addition of tea saponins and soybean oil on methane production, fermentation and microbial population in the rumen of growing lambs. Livest. Sci.129:56-62. https://doi. org/10.1016/j.livsci.2009.12.011

Munguia, B., M. Michelena, E. Melian, J. Saldana, X. Ures, E. Manta, \& L. Domínguez. 2015. Development of novel valerolactam-benzimidazole hybrids anthelmintic derivatives: Diffusion and biotransformation studies in helminth parasites. Exp. Parasitol. 153: 75-80. https://doi. org/10.1016/j.exppara.2015.03.013

Molento, M. B., F. Fortes, D. Pondelek, F. A. Borges, A. C. S. Chagas, J. F. J. Torres-Costa, \& F. Geldhof. 2011. Challenges of nematode control inruminants: focus on Latin America. Vet. Parasitol. 180: 126-132. https://doi. org/10.1016/j.vetpar.2011.05.033
Martínez-Ortíz-de-Montellano, C., C. Arroyo-López, I. Fourquaux, J. F. J. Torres-Acosta, C. Sandoval-Castro, \& H. Hoste. 2013. Scanning electron microscopy of Haemonchus contortus exposed to tannin-rich plants under in vivo and in vitro conditions. Exp. Parasitol. 133:281-286. https://doi.org/10.1016/j.exppara.2012.11.024

Nery, P. S., F. A. Nogueira, E. R. Martins, \& E. R. Duarte. 2010. Effect of Anacardium humile on the larval development of gastrointestinal nematodes of sheep. Vet Parasitol. 171:361-364. https://doi.org/10.1016/j.vetpar.2010.03.043

Ng, M. K., N. Y. Abdulhadi, Y. K. Cheah, S. K. Yeap, \& N. B. Alitheen. 2012. Bioactive studies and chemical constituents of Murraya paniculata (Linn) Jack. IFRJ 19:1307-1312.

Page , P. A., G. Stepek, A. D. Winter, \& D. Pertab. 2014. Enzymology of the nematode cuticle: A potential drug target?. Int. J. Parasitol. 4: 133-141. https://doi.org/10.1016/j. ijpddr.2014.05.003

Syahadat, R. M. \& S. A. Aziz. 2012. Pengaruh komposisi media dan fertigasi pupuk organik terhadap kandungan bioaktif daun tanaman kemuning (Murraya paniculata (L.) Jack) di pembibitan.Bul. Littro. 23: 142-147.

Vaghasiya, Y., R. Dave, \& S. Chanda. 2011. Phytochemical analysis of some medical plants from western region of India. Res. J. Med. Plant 5: 567-576. https://doi.org/10.3923/ rjmp.2011.567.576

Van Wyk, J. A. \& E. Mayhew. 2013. Morphological identification of parasitic nematode infective larvae of small ruminants and cattle: A practical lab guide. Onderstepoort J. Vet. Res. 80:1-14. https://doi.org/10.4102/ojvr.v80i1.539

Wang, Y., Y. Zhang, Z. Zhu, S. Zhu, Y. Li, M. Li, \& B. Yu. 2007. Exploration of the correlation between the structure, hemolytic activity, and cytotoxicity of steroid saponins. Bioorg. Med. Chem. 15: 2528-2532. https://doi.org/10.1016/j. bmc.2007.01.058

Zanzani, S. A., A. L. Gazzonis, A. D. Cerbo, M. Varady, \& M. T. Manfredi. 2014. Gastrointestinal nematodes of dairy goats, anthelmintic resistance and practices of parasite control in Northern Italy. BMC Vet. Res.10:114-124. https:// doi.org/10.1186/1746-6148-10-114 